\title{
Continuity or Change? Leaders' Values in the Baltic Countries over Time
}

Both scientists and practitioners acknowledge leadership as a key predictor of success in organizations. Leaders' values could be a significant criterion for the analysis of changes in leadership recently. This study aims to investigate changes in leaders' values over time among Baltic countries. The results of the European Social Survey (ESS) showed that leaders' values did not significantly change over time (from 2008 to 2016). However, the expression of values significantly differed between leaders of different countries.

Keywords: values, leaders, leadership, Baltic countries, European Social Survey (ESS).

Mokslininkai ir praktikai pripažįsta vadovavimo svarbą, kad organizacija efektyviai funkcionuotų, ypatingai pabrèždami vadovo vertybių reikšmę. Šio tyrimo metu siekiama išsiaiškinti, ar (ir kaip) pakito skirtingų Baltijos šalių vadovų vertybès per 10 metų laikotarpị. Europos socialinio tyrimo (EST) duomenų analizė atskleidè, kad 2008-2016 m. vadovų vertybės statistiškai reikšmingai nepakito. Visgi užfiksuota statistiškai reikšmingų vadovų vertybių skirtumų tarp šalių.

Raktiniai žodžiai: vertybès, vadovai, vadovavimas, Baltijos šalys, Europos socialinis tyrimas (EST).

\section{Introduction}

Both pioneers and recent leadership researchers admit that the phenomenon of leadership is one of the most observed, studied and least understood, clearly defined especially talking about the parameters of effective leadership (Burns, 1978; Van Knippenberg, Sitkin, 2013). In order to structure the extensive literature, answers to the questions about leadership in the form of theoretical insights and empirical evidence are generally grouped into two broad categories: traditional (old) and modern (new) leadership schools (Avolio, Walumbwa, Weber, 2009). It should be noted that the modern view in leadership has already experienced quite a long history since the debut of Transformational leadership. It has also encompassed different theories and models that need to be reflected over time (Hernandez et al., 2011).

The meaning of values in new leadership schools could be the main criterion for the reflection. First of all, dynamic and unstable norms and roles in the community and institutions stimulated the change of focus from managerial principles to

\footnotetext{
Aurelija STELMOKIENE - PhD, assoc. professor, Dean of the Faculty of Social Sciences, Vytautas Magnus University, Lithuania. Address: Jonavos str. 66-328, Kaunas, Lithuania. Phone: +370 37327824.

E-mail: aurelija.stelmokiene@vdu.lt
}

Karina KRAVČENKO - PhD student at the Faculty of Social Sciences, Vytautas Magnus University, Lithuania. Address: Jonavos str. 66-328, Kaunas, Lithuania. Phone: +370 37327 824. E-mail: karina.kravcenko@vdu.lt 
interpersonal values as the key predictors of success in organizational settings (Bauman, 2005). Personal and professional values were also identified as the essential factors for "good" leadership in different cultures (e.g. among Australian executives as well as among their Russian, Japanese and Chinese counterparts) (Sarros, Santora, 2001). Moreover, H. Leroy et al. (2018) proposed the value-framework of S. H. Schwartz (1999) as one of the appropriate options to analyse transformational, transactional, servant, ethical, authentic, shared and inclusive leadership, and leader-member exchange integrally. Values based leadership highlighted moral, authentic, ethical dimensions of leader behaviour and analysed such leadership traits as concern for others, integrity, role modelling, and ethical decision making (Copeland, 2014; Brown, Trevino, 2006).

Nevertheless, it should be admitted that intense contextual changes over the last decade especially in the Baltic countries (e.g. consequences of independence, the new membership in EU, financial crisis, social policy issues, etc. (Aidukaite, 2013) could influence leaders' value system. This seems to be true because leadership is defined as "a dynamic phenomenon which is strongly dependent on the needs and structures of societies" that experience different challenges in different periods of time (Marques, 2015, p. 1318). Such contextual factors as globalization, technology, ethical concerns, diversification of the workforce can't be ignored (Lord et al., 2017). Therefore, in order to answer if the values of leaders have changed over time among the Baltic countries as a reflection of contextual changes empirical research is necessary.
Leaders' personal values were considered as a factor that could help to reflect the changes in leadership (especially with reference to modern leadership approaches) over time. Moreover, cultural context (data of three Baltic countries) was included in the analysis as a significant variable that has had controversial results to date. European Social Survey data of five rounds (every two years face to face interviews are conducted with newly selected, cross-sectional samples across Europe) was used to answer the main question stable or changing trajectory represents leaders' values in Baltic countries over time.

The research object is changes in leaders' personal values in the different Baltic countries (Lithuania, Estonia and Poland) over time.

The aim of the present study is to investigate if the values of leaders have changed over time among the Baltic countries. We hypothesized that leaders' selftranscendence and openness to change values have increased while self-enhancement and conservation values have decreased over time. Moreover, it was predicted that the value change trajectories of leaders in Baltic countries are the same. In the next sections, we review the previous studies focused on values and recent changes in the context of leadership.

The research methods. To achieve the aim and to test hypothesized presumptions, secondary data analysis was applied. We used the European Social Survey (ESS) data of rounds 4-8. ESS provides high-quality comparative data on public attitudes, beliefs and behaviour patterns in different European countries. All data was collected via face-to-face interviews. 


\section{Literature review}

\subsection{Values in leadership}

With the growing attention to ethics in the leadership context studies of the leader's personal values came on the scene (Sarid, 2016). In the context of ethical scandals in business and politics (e.g. financial greed and corruption, corporate meltdowns, spiralling unethical practices) and mistrust in leader's moral standards, a moral character of a leader was validated as a necessary part of the leadership definition (Levine, Boaks, 2014; Copeland, 2014; Resnick, 2004). Moreover, an ethical leader with a strong value system was associated with effectiveness and investor trust, which was previously ruined with a high cost for organizations (Copeland, 2014; Ciulla, 2012; Jennings, 2005). In the particular case of lean-team performance leaders' self-transcendence values had a positive effect on lean-team effectiveness and conservation values - a negative one (Van Dun, Wilderom, 2016).

The refined theory of basic individual values (Schwartz et al., 2012) is the main one that researchers use in their studies investigating the meaning of values in work settings. The theory proposes 10 basic values and four value clusters: selftranscendence, self-enhancement, conservation and openness to change that are represented on two continuums from social to personal focus and from growth/ anxiety free to self-protection/ anxietyavoidance. The main assumption of the theory is that "values form a circular motivational continuum" (Schwartz et al., 2012, p. 665).
A. Bardi and S. H. Schwartz (2003) confirmed that values do motivate behavior. So, researchers were encouraged to unearth the value systems that are crucial in directing individuals in organizations (Leroy et al., 2018). It was believed that these findings could help to explain how individuals are motivated to make extra efforts at work in terms of performance. For example, A. L. Nichols and C. A. Cottrell (2014) found that followers were showing extra effort when they were able to trust their leaders.

It should be noted that the demands of Western Europe's modern era could differ in comparison with previous ones in other countries. Moreover, it is presumed that "values-based leadership evolved as a bi-product of the time and culture" (Copeland, 2014, p. 105). Therefore, the leader's values should be investigated in the context of changes over time and among cultures.

\subsection{Recent changes in the context of leadership}

Time perspective: changes of the leader's values over time

J. Marques (2015) identified four main drivers of the changed leadership landscape in the period between 2005 and 2014. They are 1) shifts in societal values, 2) shifts in investor focus, 3) ability to lead organizational change and 4) the influence of excessive stress on employees. All these multiple aspects require consideration of leader's ethics and values (Marques, 2015; Higgs, 2003).

With reference to changes in societal values, behavioural trends of today's leaders are related to their flexibility, care, sense of community, creativity, inspiration, 
facilitation and honesty (Marques, 2015). So, it could be stated that reflectiveness and relationship orientation have replaced the dominance of competitiveness and task orientation in leadership (Dinh et al., 2014; Behrendt, Matz, Goritz, 2017; Marques, 2015), because it relates to higher performance and extra efforts from employees' side. Moreover, current effective lean management is positively associated with leader's self-transcendence values (e.g. concern, tolerance, caring) and negatively - with conservation values (e.g. conformity, tradition, rules) presented in S. H. Schwartz and colleagues (2012) refined theory of basic individual values (Van Dun, Wilderom, 2016). Openness to change is crucial for leading organizational change processes, as well. A leader's intrinsic interest in novelty and mastery helps to deal with constant changes in the micro and macro context of the organization (Schwartz, 2012; Sagiv, Schwartz, Arieli, 2011).

The new generation of employees is also a very strong driver for changes in leadership. Different personalities, the variety of their expectations and attitudes to the work pose unique challenges for organizational leaders (Anderson et al., 2017). J. S. Stewart et al. (2017) argue that managers should change their focus and make some revisions in their behaviour: ordinary employees' duties should be related to bigger aims of the organization; more frequent recognition from a leader and non-financial rewards are necessary. Besides, open communication, close relationships and team environment have become the main drivers for new employees. So, the importance of leaders' openness to change and self-transcendence values are expected to grow more and more.
Finally, even the history of leadership theories can propose some trajectories for changes in leader values (Lord et al., 2017). Shift from social behaviour to cognitive explanations and focus on change agency in leadership represents three waves of leadership research. However, understanding that leadership is a social relationship has not changed (Lord et al., 2017). Therefore, the leader's selftranscendence values could be higher than self-enhancement despite the time, but conservation values should decrease together with the increase of the leader's openness to change.

Hence, with reference to the studies presented above, it is hypothesized that the values of leaders have changed over time in the Baltic countries:

- leaders' self-transcendence and openness to change values have increased over time;

- leaders' self-enhancement and conservation values have decreased over time.

\section{Place perspective: changes of the leader's values among the Baltic countries}

Although according to S. H. Schwartz (1992) basic values are recognized in all societies (e.g. in the vast majority of nations studied in cross-cultural research the top three values are benevolence, universalism and self-direction (Schwartz, 2012), their change trajectories over time could vary among countries. The Baltic countries (Estonia, Latvia, Lithuania, and Poland) are quite young members of the European Union (EU member countries since 2004). Their developing cultural context could differ in comparison with older European countries (e.g. Germany, France, Spain) the main 
results of leadership research are coming from (Lee, Scandura, Sharif, 2014). Even S. H. Schwartz et al. (2012) acknowledge the limitation that most countries in their original research were relatively high in socioeconomic level, therefore, other world regions need to be included in further studies. Researchers admit that crosscultural differences in values may depend on the country level because of different economic development, recent socio-political context, migration rates, religion, recent and past history, etc. (Tulviste, Kall, Rämmer, 2017).

Besides, it seems, that all Baltic countries experienced quite similar contextual challenges, however, their reactions and solutions to those challenges varied from country to country (Aidukaite, 2013). For example, T. Tulviste and colleagues (2017) found that the value preferences of Estonian respondents were similar to Finnish and Swedish ones, but not to Latvian or Lithuanian. J. Levina, K. Mārtinsone and K. Klince (2016) concluded that there existed both similar and specific patterns of relations between anomia and values among inhabitants of Latvia, Estonia and Lithuania. M. Huettinger (2008) added that similarities that were associated with the Baltic countries in the field of leadership needed further confirmation. So, Baltic countries have both common and specific social, economic, political and cultural contextual factors that could determine leaders' values and the question of how leader values have changed over time in different Baltic countries is still unanswered.

Results from cross-cultural research revealed that leaders from countries of embedded and hierarchical culture versus autonomous and egalitarian tended to rely upon established, traditional group norms, to be concerned about power and control whereas the importance of mastery versus harmony was related to leader's reliance on vertical sources of guidance and emphasis of striving, success (Sagiv et al., 2011). Moreover, "the prevailing cultural value orientations in societies influence managers' personal values" (Sagiv et al., 2011, p. 23). According to S. H. Schwartz (2006) values of individuals in the Baltic region differ both among other regions and within the Eastern Europe region it belongs to. The main differences are related to lower importance to tradition and conformity values and higher importance to self-direction values. East Central European region (Latvia, Estonia and Poland are in) is characterized by the lowest scores of hierarchy and high scores of intellectual autonomy and harmony in comparison with other regions (Schwartz, 2013). However, differences in economic growth, social development, democratization processes and historical events that could influence value change trajectories in the Baltic countries are very slight (Liubinienè, 2003).

Thus, the second hypothesis states that value change trajectories of leaders in the Baltic countries are the same.

\section{Methodology}

\subsection{Data collection and samples}

The European Social Survey (ESS) data from rounds 4, 5, 6, 7 and 8 were analysed to test the hypotheses. ESS provides highquality comparative data on public attitudes, beliefs and behaviour patterns that 
includes questions on human values based on the Schwartz theory (Schwartz, 2001). Lithuania joined the ESS from round 4 in 2008, therefore this study includes 5 survey waves collected in Lithuania, Poland and Estonia from 2008 through 2016. Unfortunately, Latvian data was excluded from analyses since this country participated in only one round. All data were collected via face-to-face interviews.

Table 1. Descriptive statistics of socio-demographic information.

\begin{tabular}{|c|c|c|c|c|c|c|}
\hline & 2008 & 2010 & 2012 & 2014 & 2016 & Total \\
\hline \multicolumn{7}{|l|}{ Lithuania } \\
\hline Respondents, $\mathrm{n}$ & 198 & 290 & 231 & 264 & 246 & 1229 \\
\hline Age (mean/SD) & $\begin{array}{l}48.76 / \\
16.527 \\
\end{array}$ & $\begin{array}{l}53.56 / \\
16.929 \\
\end{array}$ & $\begin{array}{l}48.00 / \\
15.634 \\
\end{array}$ & $\begin{array}{l}52.77 / \\
16.494 \\
\end{array}$ & $\begin{array}{l}50.86 / \\
15.451 \\
\end{array}$ & $\begin{array}{l}51.01 / \\
16.357\end{array}$ \\
\hline Male (\%) & $55.6 \%$ & $44.5 \%$ & $51.1 \%$ & $43.9 \%$ & $51.6 \%$ & $48.8 \%$ \\
\hline \multicolumn{7}{|l|}{ Education } \\
\hline Other than tertiary (\%) & $52.5 \%$ & $62.1 \%$ & $47.2 \%$ & $51.1 \% \%$ & $56.1 \%$ & $54.2 \%$ \\
\hline Tertiary (\%) & $47.5 \%$ & $37.6 \%$ & $52.4 \% \%$ & $48.5 \% \%$ & $43.9 \%$ & $45.6 \%$ \\
\hline \multicolumn{7}{|l|}{ Poland } \\
\hline Respondents, $\mathrm{n}$ & 339 & 380 & 369 & 261 & 289 & 1638 \\
\hline Age (mean/SD) & $\begin{array}{l}48.75 / \\
16.737\end{array}$ & $\begin{array}{l}48.50 / \\
15.822\end{array}$ & $\begin{array}{l}51.06 / \\
15.311\end{array}$ & $\begin{array}{c}51.799 / \\
16.695\end{array}$ & $\begin{array}{l}50.69 / \\
16.891\end{array}$ & $\begin{array}{l}50.04 / \\
16.268\end{array}$ \\
\hline Male (\%) & $56.6 \%$ & $58.7 \%$ & $59.9 \%$ & $60.9 \%$ & $59.5 \%$ & $59 \%$ \\
\hline \multicolumn{7}{|l|}{ Education } \\
\hline Other than tertiary (\%) & $73.7 \%$ & $58.2 \%$ & $64.5 \%$ & $67.4 \%$ & $61.6 \%$ & $64.9 \%$ \\
\hline Tertiary (\%) & $26.3 \%$ & $41.8 \%$ & $35.5 \%$ & $32.6 \%$ & $38.4 \%$ & $35.1 \%$ \\
\hline \multicolumn{7}{|l|}{ Estonia } \\
\hline Respondents, $\mathrm{n}$ & 473 & 464 & 627 & 609 & 504 & 2677 \\
\hline Age (mean/SD) & $\begin{array}{l}48.53 / \\
17.100\end{array}$ & $\begin{array}{l}50.56 / \\
17.251 \\
\end{array}$ & $\begin{array}{l}52.03 / \\
18.363 \\
\end{array}$ & $\begin{array}{l}51.59 / \\
17.686 \\
\end{array}$ & $\begin{array}{l}49.77 / \\
17.715 \\
\end{array}$ & $\begin{array}{l}50.63 / \\
17.709 \\
\end{array}$ \\
\hline Male (\%) & $49.3 \%$ & $47.6 \%$ & $48.8 \%$ & $45.8 \%$ & $53.2 \%$ & $48.8 \%$ \\
\hline \multicolumn{7}{|l|}{ Education } \\
\hline Less than tertiary (\%) & $75.3 \%$ & $61.2 \%$ & $57.9 \%$ & $55.3 \%$ & $56.2 \%$ & $60.6 \%$ \\
\hline Tertiary (\%) & $24.7 \%$ & $38.8 \%$ & $42.1 \%$ & $44.7 \%$ & $43.7 \%$ & $39.3 \%$ \\
\hline \multicolumn{7}{|l|}{ Total } \\
\hline Respondents, $\mathrm{n}$ & 1010 & 1134 & 1227 & 1134 & 1039 & 5544 \\
\hline Age (mean/SD) & $\begin{array}{l}48.65 / \\
16.851 \\
\end{array}$ & $\begin{array}{l}50.61 / \\
16.795\end{array}$ & $\begin{array}{l}50.98 / \\
17.048\end{array}$ & $\begin{array}{l}51.91 / \\
17.180\end{array}$ & $\begin{array}{l}50.28 / \\
16.972\end{array}$ & $\begin{array}{l}50.54 / \\
17.000\end{array}$ \\
\hline Male (\%) & $53 \%$ & $50.5 \%$ & $52.6 \%$ & $48.9 \%$ & $54.6 \%$ & $51.8 \%$ \\
\hline \multicolumn{7}{|l|}{ Education } \\
\hline Other than tertiary (\%) & $70.3 \%$ & $60.4 \%$ & $57.9 \%$ & $57.1 \%$ & $57.7 \%$ & $60.5 \%$ \\
\hline Tertiary (\%) & $29.7 \%$ & $39.5 \%$ & $41.2 \%$ & $42.8 \%$ & $42.3 \%$ & $39.5 \%$ \\
\hline
\end{tabular}


In order to measure the values of leaders, only respondents who reported that they were responsible for supervising other employees were included in the analyses. The number of respondents per round varied from 198 (Lithuania, 2008) to 627 (Estonia, 2012). The final sample consisted of 5544 leaders with a mean age of 50.54 years old. They accounted for $19.4 \%$ of the total sample. The proportions of male and female respondents were approximately equal in all 5 waves $(51.8 \%$ of a male in total). Across all countries, the majority of respondents reported having other than tertiary (non-university) education $(60.5 \%)$. For more socio-demographic details see Table 1.

\subsection{Measures}

The Portrait Values Questionnaire (PVQ) has been used to measure the values in ESS (Schwartz, 2001). It consists of 21 items which are classified into the ten basic values: self-direction, stimulation, hedonism, achievement, power, security, conformity, tradition, benevolence and universalism, as well as into the 4 higherorder values such as openness to change, conservation, self-transcendence and self-enhancement. The participants were asked to indicate how much they think a person in each statement is or is not like them on a 6-point rating scale ranging from 1 (very much like me) to 6 (not like me at all). Studies in many different countries support both construct and predictive validity of the 21-item PVQ (Schwartz, 2001).

According to the hypotheses, in order to measure changes of leaders' values over time and among Baltic countries, we chose to work with the 4 higher-order values mentioned above. Firstly, the coding of all value items was reversed (e.g. old code 1 "very much like me" = new code 6 "not like me at all" etc.). We obtained the score for each higher-order value by dividing the sum of the appropriate items by the number of items on that scale. So, the score for each value was the mean of the raw ratings given to the items for that value (the higher the mean score the higher the expression of that value).

Table 2. Cronbach's alpha of the four higher-order values in two separate samples.

\begin{tabular}{|c|c|c|c|}
\hline & \multirow[b]{2}{*}{ Number of Items } & \multicolumn{2}{|c|}{ Cronbach's alpha } \\
\hline & & $\begin{array}{l}\text { Lithuania, Poland, } \\
\text { Estonia }(\mathrm{N}=5544)\end{array}$ & $\begin{array}{l}\text { Finland, Israel, Poland, } \\
\text { Slovenia, Sweden, and } \\
\text { the UK }(\mathrm{N}=11128) \\
\text { (Schwartz, 2001) }\end{array}$ \\
\hline Openness to Change & 6 & 0.74 & 0.76 \\
\hline Conservation & 6 & 0.70 & 0.74 \\
\hline Self-Transcendence & 5 & 0.67 & 0.68 \\
\hline Self-Enhancement & 4 & 0.75 & 0.75 \\
\hline Total & 21 & 0.82 & - \\
\hline
\end{tabular}


Table 2 provides the Cronbach's alpha reliabilities of the 4 higher-order values for the combined samples of this study (Lithuania, Poland and Estonia, $\mathrm{N}=5246$ ) and previous research (Finland, Israel, Poland, Slovenia, Sweden, and the UK, N=11128) (Schwartz, 2001). The observed reliability coefficients for a sample from Lithuania, Poland and Estonia show acceptable internal consistency and are similar to those found in the previous study.

\subsection{Statistical analysis}

The ESS data was analysed using IBM Statistical Package for Social Sciences (SPSS 22). In order to test the effect of the year when ESS was carried out (2008, 2010, 2012, 2014 and 2016 - independent variable) on the 4 higher-order values (openness to change, conservation, self-transcendence, self-enhancement - dependent variables) ( $1^{\text {st }}$ hypothesis), a one-way multivariate analysis of variance (MANOVA) was conducted. A two-way MANOVA was performed when evaluating changes of values both over time and among Baltic countries ( $2^{\text {nd }}$ hypothesis) with the 4 higher-order values as dependent variables, and the year and country where ESS was carried out (Lithuania, Poland, Estonia) as independent variables. Follow-up univariate analyses of variance (ANOVAs) examined the effect of each independent variable on every dependent variable.

\section{Results}

\subsection{Changes of leaders' values over time}

Before testing the MANOVA assumptions, univariate and multivariate outliers for each value variable in all groups of the different year were excluded, leaving a sample size of 5490 respondents. A significant Box's $M$ indicated that the homogeneity of variance-covariance matrices was not observed (Box's $M$ value is 135.200, $\mathrm{p}<.001)$. Nevertheless, a oneway MANOVA can still be applied as it is believed to be robust against this violation if group sizes are over 30 (Allen, Bennett, 2008) (sample sizes of 2008, 2010, 2012, 2014 and 2016 were 1002, 1117, 1219, 1125 and 1027, respectively). Therefore, MANOVA was chosen as a proper analysis method for testing the $1^{\text {st }}$ hypothesis.

Changes in leaders' values in all Baltic countries taken together are presented in Figure 1. In the period from 2008 to 2016, the values changed unevenly. Nevertheless, the expression trends among different values remained the same with the most expressed value of self-transcendence and the least expressed self-enhancement.

Table 3. Sample sizes of all combinations of groups by year and country.

\begin{tabular}{|l|c|c|c|c|c|c|c|c|c|}
\hline \multicolumn{1}{|c|}{$\mathbf{2 0 0 8}$} & $\mathbf{N}$ & $\mathbf{2 0 1 0}$ & $\mathbf{N}$ & $\mathbf{2 0 1 2}$ & $\mathbf{N}$ & $\mathbf{2 0 1 4}$ & $\mathbf{N}$ & $\mathbf{2 0 1 6}$ & $\mathbf{N}$ \\
\hline Lithuania & 195 & Lithuania & 281 & Lithuania & 230 & Lithuania & 259 & Lithuania & 242 \\
\hline Poland & 337 & Poland & 372 & Poland & 364 & Poland & 259 & Poland & 284 \\
\hline Estonia & 466 & Estonia & 462 & Estonia & 623 & Estonia & 600 & Estonia & 500 \\
\hline
\end{tabular}




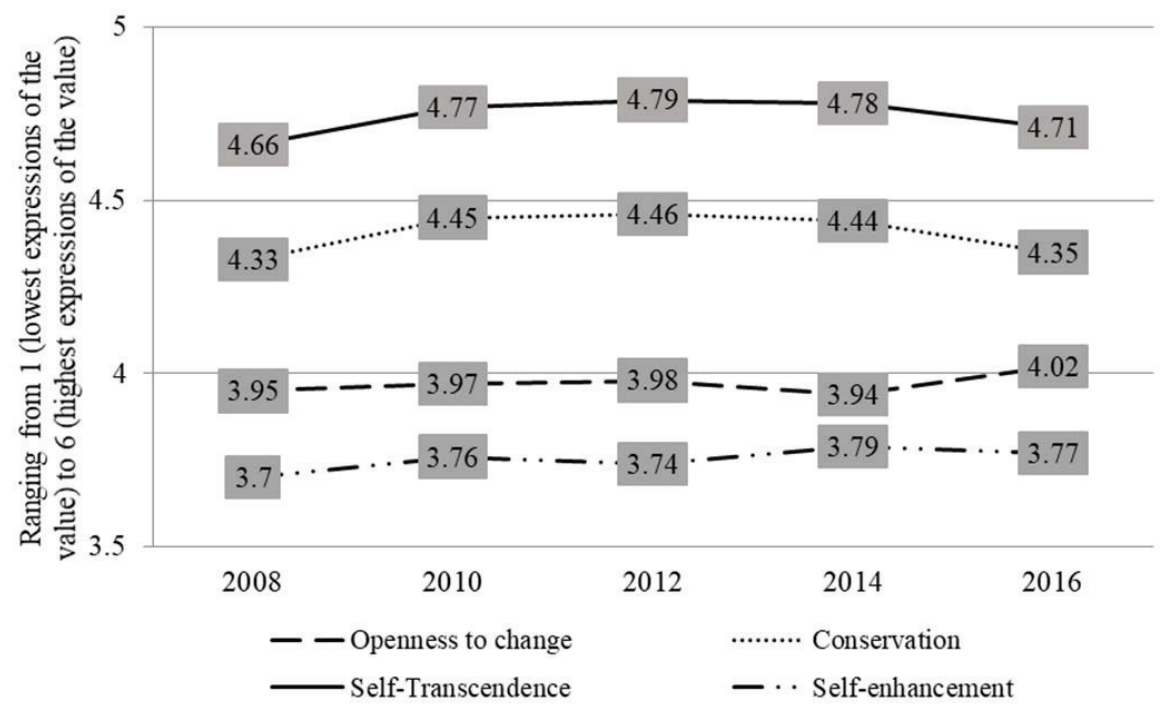

Fig. 1. Changes of leaders' values in the Baltic countries

Mean scores of each value for different years varied in the range of $.08-.13$, suggesting that there were no radical changes over time. Nevertheless, the effect of the year was statistically significant (Pillai's Trace $=.009, F(16)=3.216, p<.001, \eta_{p}{ }^{2}=$ $.002)$.

The homogeneity of variance was not assumed for 3 out of 4 dependent variables, therefore we chose a stricter alpha level of .001 to evaluate univariate effects. The $\mathrm{F}$ tests showed significant differences between different year only for conservation $(F(4)=6.785, p<.001)$ and self-transcendence $(F(4)=3.337, p<.001)$ values. However, the effect sizes were extremely small $\left(\eta_{p}^{2}=.005\right.$, for both values). Posthoc analysis revealed that both conservation and self-transcendence values significantly increased from 2008 to 2014 (p $<.05)$ but decreased to a non-significant level in 2016 ( $p>.05)$. With reference to the results presented above, it should be stated that leaders' values did not change significantly over time and, thus the $1^{\text {st }}$ hypothesis was not confirmed.

\subsection{Changes of leaders' values over time and among the Baltic countries}

After excluding univariate and multivariate outliers for each value variable in all combinations of groups by year and country, a final sample size left with 5475 respondents. Despite the violated assumption about the homogeneity of variance-covariance matrices (Box's M value is $138.424, \mathrm{p}<.001)$, we further performed a two-way MANOVA analysis since the size of each group in this study was way over 30 (see Table 3).

Both year and country had a significant effects on values (Pillai's Trace $=$ $.013, F(16)=4.490, p<.001$ and Pillai's Trace $=.292, F(8)=232.771, p<.001$, respectively) but with a stronger effect of country than year $\left(\eta_{p}^{2}=.146\right.$ and $\eta_{p}{ }^{2}=$ 


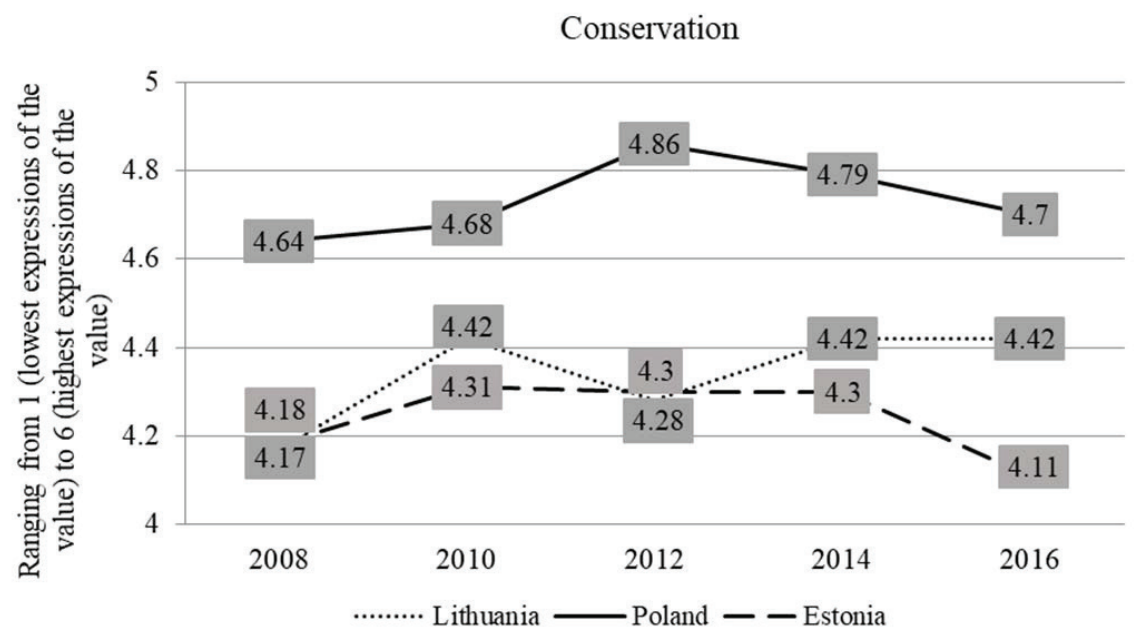

Fig. 2. Change trajectory of the leaders' conservation value in the separate Baltic countries

.003 , respectively). This indicates that expression of values varied more among different Baltic countries than over time when taking all countries together. The interaction effect of year and country on values was also significant (Pillai's Trace $=$ $\left..02, F(32)=3.487, p<.001, \eta_{p}^{2}=.005\right)$. It means that the effect of year was different for Lithuania, Poland and Estonia.

The homogeneity of variance for dependent variables was not assumed, therefore, we chose a stricter alpha level of .001 in order to evaluate univariate effects. The F tests analyses revealed significant but small differences of changes of conservation $\left(F(8)=4.316, \eta_{p}{ }^{2}=.006, p<\right.$ $.001)$, self-transcendence $(F(8)=4.212$, $\left.\eta_{p}{ }^{2}=.006, p<.001\right)$ and self-enhancement $\left(F(8)=5.078, \eta_{p}^{2}=.007, p<.001\right)$ values of leaders over time in separate Baltic countries. Changes of openness to change value over time in separate Baltic countries were not significant $(\mathrm{p}>.05)$. Therefore, only significant change trajectories of conservation, self-transcendence and self-enhancement values in Lithuania,
Poland and Estonia are presented in Figures 2-4.

Post-hoc analyses showed no significant changes in leaders' conservation value in Lithuania over time ( $p>.05)$. In Poland these values significantly increased from 2008 to $2012(\mathrm{p}<.05)$ whereas in Estonia they significantly decreased from 2010 to $2016(\mathrm{p}<.05)$. Although the expression of leaders' conservation value was highest in Poland, the change between 2008 and 2016 was not significant neither in Poland nor in Estonia or Lithuania.

Leaders' self-transcendence value had some significant differences over time in all countries. It significantly increased from 2008 to 2010 in Lithuania and from 2010 to 2012 in Poland $(\mathrm{p}<.05)$. More changes of leaders' self-transcendence values over time were observed in Estonia: there were significant differences between 2008 and 2010, 2012, 2014 $(\mathrm{p}<.05)$. Moreover, Lithuania could be characterized as a country with the lowest scores of leaders' self-transcendence value in comparison with Poland and Estonia. 


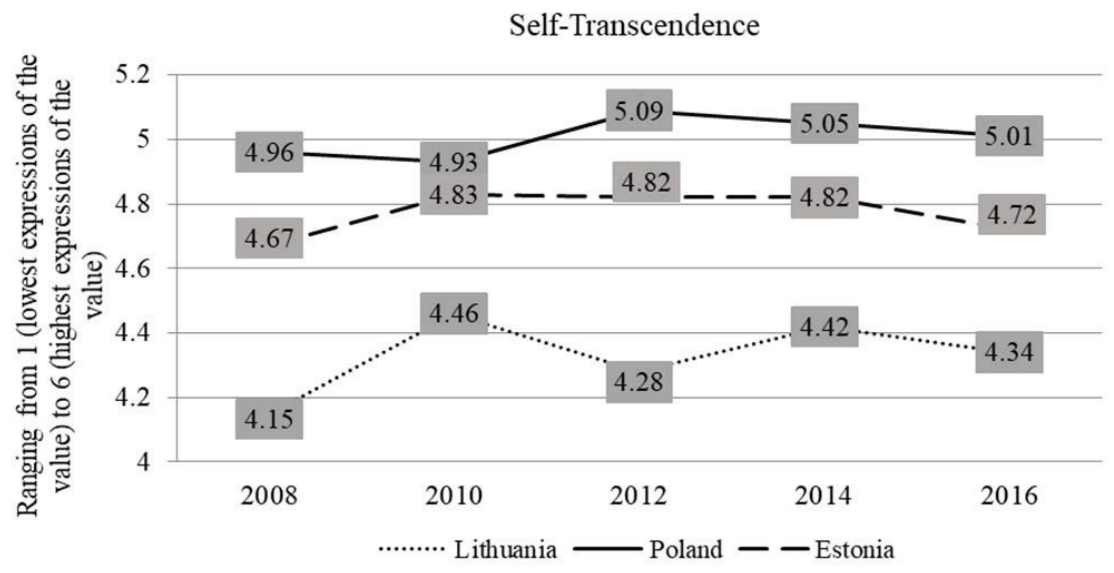

Fig. 3. Change trajectory of the leaders' self-transcendence value in the separate Baltic countries

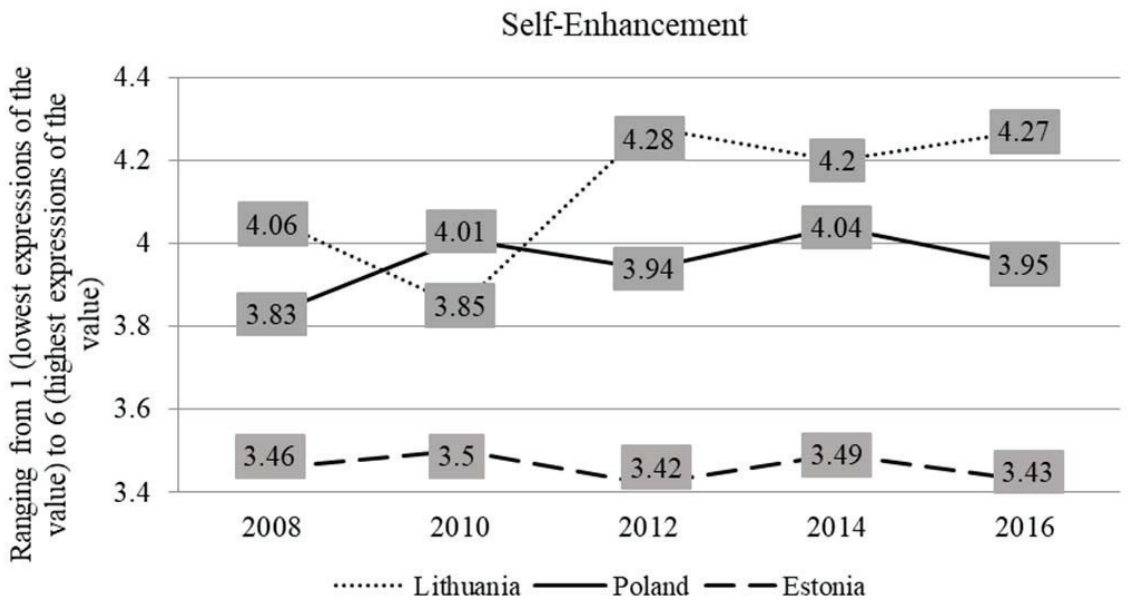

Fig. 4. Change trajectory of the leaders' self-enhancement value in the separate Baltic countries

However, change trajectories of this value were quite similar: no differences of selftranscendence were observed between 2008 and 2016 in any country ( $p>.05)$.

No significant differences in leaders' self-enhancement scores over years were obtained neither in Poland nor in Estonia ( $p$.05). In Lithuania, the leaders' self-enhancement values significantly increased from 2010 and remained the same until 2016. Nevertheless, no significant changes in these values were observed between 2008 and 2016 ( $p>$ >05). However, it should be admitted that the expression of the leaders' self-enhancement value in Estonia was the lowest in comparison with Lithuania and Poland. 
With reference to the results presented above, the $2^{\text {nd }}$ hypothesis should be confirmed. Although there were minor differences between the expression of particular leaders' values over some years that varied among countries, taking into account the period from 2008 to 2016 changes of leaders' values were not significant neither in Poland, nor in Lithuania or Estonia. However, it should be noted that the effect of the country on changes of leaders' values over time (self-enhancement, self-transcendence and conservation) was significant. Therefore, differences in the 4 higher-order leaders' values among Baltic countries need further investigation.

\section{Discussion}

The main aim of the research was to investigate if the values of leaders have changed over time among Baltic countries as a reflection of contextual changes. Both time (period of 2008-2016) and place (Estonia, Lithuania and Poland) perspectives were considered when analysing the 4 higherorder values of leaders and their change trajectories. Leaders' values were chosen as a criterion to reflect the changes in leadership over time.

\subsection{Changes of leaders' values over time}

Data analysis revealed that only two leaders' values changed significantly over years: conservation and self-transcendence values significantly increased from 2008 to 2014 but decreased to a nonsignificant level in 2016. The change trajectory of these values is nonlinear and looks like an inverted slight $U$ shape. As it was supposed that leaders' self-transcendence and openness to change values had increased and leaders' self-enhancement and conservation values had decreased over time, the $1^{\text {st }}$ hypothesis was not confirmed by empirical data. The biggest surprise was related to the change trajectory of leaders' conservation values. A significant increase in leaders' conservation values from 2008 to 2014 is the opposite result than it was expected from the literature (Van Dun, Wilderom, 2016; Stewart et al., 2017). However, L. Sagiv et al. (2011) points that leaders' conservation is related to their motivation to preserve the status quo through tradition and conformity in order to ensure the security of a team, organization, society. Leaders' role in dealing with constant changes is crucial and conservation values can also help to manage these processes through the promotion of obedience to authority (Sagiv et al., 2011). Besides, leaders' motivation to find safety and stability for others is related to self-transcendence values (e.g., benevolence).

S. H. Schwartz (2012) presented the 4 higher-order values as an integrated model, therefore, changes in the dominance of different leaders' values over years were also important for the data analysis. With reference to the research results, the expression trend among different leaders' values over years remained the same with the most expressed values of selftranscendence and the least expressed self-enhancement. Moreover, leaders' conservation values were higher than the openness to change. Results of the research represent the idea of the theoretical values model where self-enhancement 
and self-transcendence values are different sides of the one continuum and conservation and openness to change values conflicts on the other continuum (Schwartz, 2012). It seems that for leaders the bigger gap is between the expression of self-transcendence and self-enhancement values, when leaders place the biggest emphasis on concern for the welfare and interests of others. Findings are in line with other research that highlights the importance of leaders' care, communication with employees, tolerance, recognition and relationship orientation in the new era of leadership (Dinh et al., 2014; Behrendt et al., 2017; Marques, 2015, van Dun, Wilderom, 2016, Stewart et al., 2017). So, leadership is more about social change processes than about individuals (Lord et al., 2017).

\subsection{Changes of leaders' values among the Baltic countries over time}

Further data analysis showed that the effect of the research year on the change of leaders' values was different for Lithuania, Poland and Estonia. Only three of four higher-order values (conservation, selftranscendence and self-enhancement) changed significantly over the years when analysing leaders from the different Baltic countries. These changes were very slight and related to differences between the particular years but not to the whole period of time used in the analysis (2008-2016). Therefore, it is really hard to present the clear, unambiguous tendencies of leaders' values changes among the Baltic countries over time. It could be that those small individual changes were related to the unique contextual events country experienced during the period of research. Therefore, a sociological viewpoint could propose additional insights. However, results were in line with the proposition from the literature review that value change trajectories of leaders in different Baltic countries are the same. As V. Liubiniene (2003) stated, differences in economic growth, social development, democratization processes and historical events that could influence value change trajectories in Baltic countries were very slight. Besides, Lithuania, Latvia, Estonia and Poland experienced quite similar contextual challenges over time in comparison with other countries (Aidukaite, 2013). So, leaders from different countries had to deal with comparable issues over time.

The expression of leaders' values varied more among the different Baltic countries than over time. Various researchers (Tulviste et al., 2017; Levina et al., 2016; Huettinger, 2008) proposed that there should be some value differences among the Baltic countries and this research revealed the exact ones: Poland had the highest scores of leaders' conservation values, Lithuania had the lowest scores of leaders' self-transcendence values and Estonia had the lowest scores of leaders' self-enhancement values. It could be that the impact of nation-level values was the main factor for such results (Sagiv et al., 2011). As organizations are nested within societies, national culture can't be ignored in order to function effectively. Therefore, leaders' values have to be compatible with the surrounding context. With reference to country comparison from Hofstede insights (n.d.), Poland has higher scores in comparison with Lithuania and Estonia on power distance, masculinity, uncertainty avoidance, indulgence and lower scores 
on long-term orientation. Individualism scores are equal among all three countries. Masculinity is the only dimension Lithuania and Estonia differ in (lower scores for Lithuania). So, Hofstede's cultural dimensions can help to explain high scores of leaders' conservation values in Poland: hierarchical normative society with a high preference for avoiding uncertainty relates with leaders' resistance to change, the importance of order and control. With low scores of masculinity, both Estonia and Lithuania should be feminine countries that are driven by liking what you do, not competition or achievement. Democratic and consultative management style preferred in these societies should be related to low self-enhancement and high self-transcendence values of leaders.

\section{Limitations}

There was used data from five rounds of the European Social Survey - academically driven cross-national survey with high methodological standards. However, the study has several limitations. First, samples in different rounds are representative, nevertheless, different people participate in different rounds. Therefore, longitudinal processes of leaders' values can't be grasped. Besides, data from Latvia was not included because the country participated only in round 3 and round 4 . As the aim of the study was to investigate changes in leaders' values among the Baltic countries, there is a lack of full view across the Baltic region. Finally, the mean age of respondents was 51 years. It could be that values differ among younger and older leaders. So, this time the data represented the values of older leaders.

\section{Conclusions and implications}

1. The study adds knowledge to leadership and cross-cultural research:

a. Results of the research revealed that leaders' values were more stable than it was expected. Only two leaders' values changed significantly over years: conservation and self-transcendence values significantly increased from 2008 to 2014 but decreased to a non-significant level in 2016.

b. However, data proposed some interesting facts about the dominance of the particular leaders' values and differences of leaders' values among the Baltic countries. The expression trend among different leaders' values over years remained the same with the most expressed values of self-transcendence and the least expressed - selfenhancement. Moreover, Poland had the highest scores of leaders' conservation values, Lithuania had the lowest scores of leaders' selftranscendence values and Estonia had the lowest scores of leaders' self-enhancement values.

c. Further interdisciplinary research is necessary to investigate reasons of different leaders' values among countries and slight changes over time.

2. Some practical implications could also be recommended:

a. Leaders' values matter in the practice of organizations. "Investing 
in human beings is important in creating welfare (for organizations and individuals alike)" (Leroy et al., 2018, p. 249). Organizations quite often allocate the major part of their investments to leaders as the main figures who predict organizational success (Archer, 2013). Leader's values play a great role in managing people (Leroy et al., 2018). Therefore, they need to be considered during the selection and promotion processes and in the developmental programs for leaders on purpose to justify the investments:

i. Self-transcendence values of candidates should be assessed during the selection and promotion procedures for leadership positions. ii. Whereas, openness to change values should be included in the developmental programs for leaders.

b. International organizations should consider differences in leaders' values among countries as they could be related to nation-level values. So, one approach does not fit all. Modifications of human management actions should be based on empirical evidence about cultural differences mentioned above.

\section{Acknowledgment}

The preparation of the article was supported by the Research Council of Lithuania (Grant No. VS-3).

\section{References}

1. Aidukaitè, J. (2013). Social Policy Changes in the three Baltic States over the Last Decade (20002012) // Ekonomika. Vol. 92, No. 3, pp. 89-104. doi: 10.1080/01629778.2019.1570958

2. Allen, P., Bennett, K. (2008). SPSS for the Health \& Behavioural Sciences. - South Melbourne, Victoria, Australia: Thomson.

3. Anderson, H. J., Baur, J. E., Griffith, J. A., Buckley, M. R. (2017). What Works for You May Not Work For (Gen) Me: Limitations of Present Leadership Theories for the New Generation // The Leadership Quarterly. Vol. 28, No. 1, pp. 245-260. doi: 10.1016/j.leaqua.2016.08.001

4. Archer, S. (2013). Leadership DevelopmentCan there be a Return on Investment? // Development and Learning in Organizations: An International Journal. Vol. 27, No. 3, pp. 1821. doi: $10.1108 / 14777281311315865$

5. Avolio, B. J., Walumbwa, F., Weber, T. J. (2009). Leadership: Current Theories, Research, and Future Directions // Annual Review of Psychology. Vol. 60, pp. 421-449. doi: 10.1146/ annurev.psych.60.110707.163621
6. Bardi, A., Schwartz, S. H. (2003). Values and Behavior: Strength and Structure of Relations // Personality and Social Psychology Bulletin. Vol. 29, No. 10, pp. 1207-1220. doi: 10.1177\%2F0146167203254602

7. Bauman, Z. (2005). Education in Liquid Modernity // The Review of Education, Pedagogy, and Cultural Studies. Vol. 27, No. 4, pp. 303-317. doi: 10.1080/10714410500338873

8. Behrendt, P., Matz, S., Goritz, A. S. (2017). An Integrative Model of Leadership Behavior // The Leadership Quarterly. Vol. 28, pp. 229-244. doi: 10.1016/j.leaqua.2016.08.002

9. Brown, M. E., Treviño, L. K. (2006). Ethical Leadership: A Review and Future Directions // The Leadership Quarterly. Vol. 17, No. 6, pp. 595-616. doi: 10.1016/j.leaqua.2006.10.004

10. Burns, J. M. (1978). Leadership. - Harper \& Row, New York.

11. Ciulla, J. B. (2012). Ethics Effectiveness: The Nature of Good Leadership / In the Nature of Leadership, ed. D. V. Day and J. Antonakis. 2nd ed. - Los Angeles, CA: 
Sage, pp. 508-540. Internet access: https:// scholarship.richmond.edu/cgi/viewcontent. cgi ? article $=1016 \&$ context $=$ jepson - facultypublications Copeland, M. K. (2014). The Emerging Significance of Values Based Leadership: A Literature Review // International Journal of Leadership Studies. Vol. 8, No. 2, pp. 105-135. Internet access: https://www. regent.edu/acad/global/publications/ijls/new/ vol8iss2/6-Copeland.pdf

12. Dinh, J. E., Lord, R. G., Gardner, W. L., Meuser, J. D., Liden, R. C., Hu, J. (2014). Leadership Theory and Research in the New Millennium: Current Theoretical Trends and Changing Perspectives // The Leadership Quarterly. Vol. 25, No. 1, pp. 36-62. doi: 10.1016/j.leaqua.2013.11.005

13. ESS Round 4: European Social Survey Round 4 Data (2008). Data file edition 4.5. NSD Norwegian Centre for Research Data, Norway Data Archive and distributor of ESS data for ESS ERIC. doi: 10.21338/NSD-ESS4-2008

14. ESS Round 5: European Social Survey Round 5 Data (2010). Data file edition 3.4. NSD Norwegian Centre for Research Data, Norway Data Archive and distributor of ESS data for ESS ERIC. doi: 10.21338/NSD-ESS5-2010

15. ESS Round 6: European Social Survey Round 6 Data (2012). Data file edition 2.4. NSD Norwegian Centre for Research Data, Norway Data Archive and distributor of ESS data for ESS ERIC. doi: 10.21338/NSD-ESS6-2012

16. ESS Round 7: European Social Survey Round 7 Data (2014). Data file edition 2.2. NSD Norwegian Centre for Research Data, Norway Data Archive and distributor of ESS data for ESS ERIC. doi: 10.21338/NSD-ESS7-2014

17. ESS Round 8: European Social Survey Round 8 Data (2016). Data file edition 2.1. NSD Norwegian Centre for Research Data, Norway Data Archive and distributor of ESS data for ESS ERIC. doi: 10.21338/NSD-ESS8-2016

18. Hernandez, M., Eberly, M. B., Avolio, B. J., Johnson, M. D. (2011). The Loci and Mechanisms of Leadership: Exploring a More Comprehensive View of Leadership Theory // The Leadership Quarterly. Vol. 22, pp. 11651185. doi: 10.1016/j.leaqua.2011.09.009

19. Higgs, M. (2003). How Can We Make Sense of Leadership in the 21st Century? // Leadership \& Organization Development Journal. Vol. 24, No. 5, pp. 273-284. doi: $10.1108 / 01437730310485798$
20. Hofstede Insights (n.d.). Compare countries. Internet access: <https://www.hofstede-insights. com/product/compare-countries/>, [accessed November 12, 2019].

21. Huettinger, M. (2008). Cultural Dimensions in Business Life: Hofstede's Indices for Latvia and Lithuania // Baltic Journal of Management. Vol. 3, No. 3, pp. 359-376. doi: $10.1108 / 17465260810902414$

22. Jennings, M. M. (2005). Ethics and Investment Management: True Reform // Financial Analysts Journal. Vol. 61, No. 3, pp. 45-58. doi: 10.2469/ faj.v61.n3.2727

23. Lee, K., Scandura, T. A., Sharif, M. M. (2014). Cultures have Consequences: A Configural Approach to Leadership Across Two Cultures // The Leadership Quarterly. Vol. 25, pp. 692-710. doi: 10.1016/j.leaqua.2014.03.003

24. Leroy, H., Segers, J., van Dierendonck, D., Den Hartog, D. (2018). Managing People in Organizations: Integrating the Study of HRM and Leadership // Human Resource Management Review. Vol. 28, pp. 249-257. doi: 10.1016/j.hrmr.2018.02.002

25. L,evina, J., Mārtinsone, K., Klince, K. (2016). Relations between Anomia and Values of the Inhabitants of the Baltic States // In Society, integration, education proceedings of the international scientific conference. Vol. I, pp. 431-446. doi: 10.17770/sie2016vol1.1522

26. Levine, M. P., Boaks, J. (2014). What does Ethics have to do with Leadership? // Journal of Business Ethics. Vol. 124, pp. 225-242. doi: 10.1007/s10551-013-1807-y

27. Liubinienè, V. (2003). Value Orientations in Estonian and Lithuanian Society: Sociological Analysis from the Gender and Age Perspective // Socialiniai mokslai. Vol. 3, pp. 48-55. https://etalpykla.lituanistikadb.lt/object/ LT-LDB-0001:J.04 2003 1367187631607 /J.04 2003 1367187631607.pdf

28. Lord, R. G., Day, D. V., Zaccaro, S. J., Avolio, B. J., Eagly, A. H. (2017). Leadership in Applied Psychology: Three Waves of Theory and Research // Journal of Applied Psychology. Vol. 102, No. 3, pp. 434-451. doi: 10.1037/ apl0000089

29. Marques, J. (2015). The Changed Leadership Landscape: What Matters Today // Journal of Management Development. Vol. 34, No. 10, pp. 1310-1322. doi: 10.1108/JMD-02-2015-0010

30. Nichols, A. L., Cottrell, C. A. (2014). What do People Desire in their Leaders? The Role of 
Leadership Level on Trait Desirability // The Leadership Quarterly. Vol. 25, No. 7, pp. 11729. doi: 10.1016/j.leaqua.2014.04.001

31. Resnick, J. T. (2004). Corporate Reputation: Managing Corporate Reputation-Applying Rigorous Measures to a Key Asset // Journal of Business Strategy. Vol. 25, No. 6, pp. 30-38. doi: $10.1108 / 02756660410569175$

32. Sagiv, L. (2011). Personal Values, National Culture and Organizations: Insights Applying the Schwartz Value Framework / In the Handbook of Organization Culture and Climate, ed. N. N. Ashkanasy, C. Wilderom and M. F. Peterson, 2nd edition - Newbury Park, CA: Sage, pp. 515-537. doi: 10.4135/9781483307961. n29

33. Sarid, A. (2016). Integrating Leadership Constructs into the Schwartz Value Scale: Methodological Implications for Research // Journal of Leadership Studies. Vol. 10, No. 1, pp. 8-17. doi: 10.1002/jls.21424

34. Sarros, J. C., Santora, J. C. (2001). Leaders and Values: A Cross-cultural Study // Leadership \& Organization Development Journal. Vol. 22, No. 5, pp. 243-248. doi: 10.1108/01437730110397310

35. Schwartz, S. H. (1992). Universals in the Content and Structure of Values: Theoretical Advances and Empirical Tests in 20 Countries / In Advances in Experimental Social Psychology, ed. M. P. Zanna. - Academic Press. Vol. 25, pp. 1-65. doi: 10.1016/S0065-2601(08)60281-6

36. Schwartz, S. H. (1999). A Theory of Cultural Values and Some Implications for Work // Applied Psychology. Vol. 48, No. 1, pp. 23-47. doi: 10.1111/j.1464-0597.1999.tb00047.x

37. Schwartz, S. H. (2003). A Proposal for Measuring Value Orientations Across Nations / In Questionnaire Package of the European Social Survey. City University London, London, pp. 261-315. Internet access: https://www. europeansocialsurvey.org/docs/methodology/ core_ess_questionnaire/ESS_core _ questionnaire_human_values.pdf

38. Schwartz, S. H. (2006). A Theory of Cultural Value Orientations: Explication and Applications // Comparative Sociology. Vol. 5, pp. $137-182$. doi: $10.1163 / 156913306778667357$
39. Schwartz, S. H. (2012). An Overview of the Schwartz Theory of Basic Values // Online Readings in Psychology and Culture. Vol. 2, No. 1, pp. 1-20. doi: 10.9707/2307-0919.1116

40. Schwartz, S., Cieciuch, J., Vecchione, M., Davidov, E., Fischer, R., Beierlein, C., Ramos, A., Verkasalo, M., Lönnqvist, J., Demirutku, K., Dirilen-Gumus, O., Konty, M. (2012). Refining the Theory of Basic Individual Values // Journal of Personality and Social Psychology. Vol. 103, No. 4, pp. 663-688. doi: 10.1037/a0029393

41. Schwartz, S. H. (2013). Culture Matters: National Value Cultures, Sources and Consequences / In Understanding Culture: Theory, Research and Application, ed. R. S. Wyer, C. Y. Chiu and Y. Y. Hong. - New York, NY: Psychology Press, pp. 127-150. Internet access: https:// www.researchgate.net/publication/274138930_ Culture_matters_National_value_cultures_ sources_and_consequences

42. Stewart, J. S., Oliver, E. G., Cravens, K. S., Oishi, S. (2017). Managing millennials: Embracing generational differences // Business Horizons. Vol. 60, No. 1, pp. 45-54. doi: 10.1016/j.bushor.2016.08.011

43. Tulviste, T., Kall, K., Rämmer, A. (2017). Value Priorities of Younger and Older Adults in Seven European Countries // Social Indicators Research. Vol. 133, No. 3, pp. 931-942. doi: 10.1007/s11205-016-1392-4

44. Van Dun, H. D., Wilderom, C. P. (2016). Leanteam Effectiveness through Leader Values and Members' Informing // International Journal of Operations \& Production Management. Vol. 36, No. 11, pp. 1530-1550. doi: 10.1108/ IJOPM-06-2015-0338

45. Van Knippenberg, D., Sitkin, S. B. (2013). A Critical Assessment of CharismaticTransformational Leadership Research: Back to the Drawing Board? // The Academy of Management Annals. Vol. 7, No. 1, pp. 1-60. doi: 10.1080/19416520.2013.759433

The paper submitted: September 20, 2020

Prepared for publication: December 10, 2020 


\section{Aurelija STELMOKIENĖ, Karina KRAVČENKO BALTIJOS ŠALIŲ VADOVỤ VERTYBIỤ POKYČIŲ IR TĘSTINUMO ANALIZE்}

\section{S a n tra u k a}

Mokslininkai bei praktikai pripažįsta vadovavimo svarbą, kad organizacija efektyviai funkcionuotų, ypatingai pabrèždami vadovo vertybių reikšmę. Išsamių tęstinių tyrimų apie Rytų Europos šalių vadovų vertybių kaitą svarbių kontekstinių pokyčių laikotarpiu trūksta, todèl šio tyrimo metu buvo siekiama išsiaiškinti, ar pakito ir kaip pakito skirtingų Baltijos šalių (Lietuvos, Estijos ir Lenkijos) vadovų vertybès per 10 metų laikotarpị.

Straipsnyje pasitelkta antrinių duomenų analizė naudojant Europos socialinio tyrimo (EST) 4-8 bangos (nuo $2008 \mathrm{~m}$. iki $2016 \mathrm{~m}$.) duomenis. Reprezentatyvią tyrimo imtị sudare 5544 Lietuvos, Estijos ir Lenkijos vadovai (iš jų 51,8 proc. vyrų), kurių amžiaus vidurkis buvo 50,54 metų. Siekiant ịvertinti vertybių pokyčius, remtasi S. H. Schwartz modeliu, todèl buvo analizuojamos 4 aukštesnio rango vertybès - konservatyvumas, atvirumas pokyčiams, investavimas ị save bei atsidavimas kitiems (skalių patikimumo rodikliai bendroje imtyje svyruoja nuo $0,67$ iki 0,75$)$.

Daugiamatès dispersinès analizès (MANOVA) rezultatai atskleide, jog bendroje imtyje nuo $2008 \mathrm{~m}$. iki $2014 \mathrm{~m}$. nežymiai sustiprejo tik konservatyvumo ir atsidavimo kitiems vertybių išreikštumas, tačiau 2016 m. vèl sumažejo ir statistiškai reikšmingai nesiskyrè nuo $2008 \mathrm{~m}$. Daroma prielaida, kad bendrai visų šalių vadovų vertybès nuo 2008 m. iki 2016 m. statistiškai reikšmingai nepakito. Nustatyta, kad minètu laikotarpiu ryškiausios buvo atsidavimo kitiems vertybès, o silpniausios - investavimo ị save vertybès. Vertinant vertybių kaitą tarp šalių pastebèta, kad tam tikros vertybès šiek tiek kito, tačiau lyginant jų išreikštumą 2008 m. ir 2016 m. statistiškai reikšmingų skirtumų nebuvo. Rezultatai atskleidè, kad minètu laikotarpiu konservatyvumo vertybès buvo ryškiausios tarp Lenkijos vadovų, atsidavimo kitiems vertybės silpniausios tarp Lietuvos vadovų, o investavimo ị save vertybès - tarp Estijos vadovų.

Tyrimo rezultatai galètų būti panaudoti planuojant / tobulinant vadovų atrankos, paaukštinimo procesus ir vystymo programas. Pavyzdžiui, siekiant efektyvaus vadovavimo, organizacijų lyderiams skirtų mokymų metu turètų būti stiprinamos atvirumo pokyčiams vertybès. Per vadovų atrankas būtų naudinga ịvertinti atsidavimo kitiems vertybių išreikštumą. Tarptautinès organizacijos turètų atkreipti dèmesị ị skirtingų šalių lyderiams būdingų vertybių skirtumus. Tolesniuose tarpkultūriniuose moksliniuose vadovavimo psichologijos tyrimuose svarbu analizuoti vertybių skirtumų tarp šalių bei minimalių vertybių pokyčių skirtumus ir ieškoti veiksnių, galinčių juos paaiškinti. 